\title{
Silica from Natural Sources: a Review on the Extraction and Potential Application as a Supporting Photocatalytic Material for Antibacterial Activity
}

\author{
Annisa Luthfiah ${ }^{1}$, Yusi Deawati ${ }^{1}$, M. Lutfi Firdaus ${ }^{2}$, Iman Rahayu ${ }^{1}$, Diana Rakhmawaty Eddy ${ }^{1 *}$ \\ ${ }^{1}$ Department of Chemistry, Universitas Padjadjaran, Jln. Raya Bandung-Sumedang Km. 21, Indonesia \\ ${ }^{2}$ Graduate School of Science Education, University of Bengkulu, Jl. W.R Supratman, Kandang Limun, Bengkulu, Indonesia \\ *Corresponding author: diana.rahmawati@unpad.ac.id
}

\begin{abstract}
Silica has become a popular material due to its high abundance and many advantages in various fields. This material can be produced synthetically and extracted from nature with resultant advantages in the application of green production. Therefore, this article deals with the form of silica extracted from quartz sand, leaves, and agricultural wastes found in nature. The extraction process from various sources would be described using thermal, biological, and chemical methods. This review also highlights the potential application of silica as a photocatalytic antibacterial-supporting material and discusses its role in increasing the effectiveness of the process. The discussion was continued with research on this procedure, where synthetic auxiliary materials were compared to the extracted silica. Furthermore, results obtained indicated that the extracted material had very good potential as a photocatalyst adjunct in its application in the antibacterial field.
\end{abstract}

Keywords

Antibacterial, Extraction Method, Silica, Support Material, Photocatalyst

Received: 23 February 2021, Accepted: 13 June 2021

https://doi.org/10.26554/sti.2021.6.3.144-155

\section{INTRODUCTION}

Silica $\left(\mathrm{SiO}_{2}\right)$ which is a constituent of silica sand and mining products, is the most occuring oxide on the planet (Lutgens and Tarbuck, 2000) after oxygen in terms of its composition (Matichenkov and Calvert, 2002). The formation of silica sand is due to the weathering process of rocks containing quartz and feldspar (Bernstein and Carpi, 2015). In addition, silicones can be produced in amorphous and crystalline forms. The center of this structure is developed from atoms containing four oxygen fused to a tetrahedral angle site close to the silicon molecule by covalent bonds (Bernstein and Carpi, 2015; Julia, 2002). Consequently, this tetrahedral structure bonds with each other and forms a large silica matrix (Salh, 2011).

The bond angle around $\mathrm{O}-\mathrm{Si}-\mathrm{O}$ is $109.5^{\circ}$, which is a tetrahedral angle and varies in length between 1.54-1.69 A. Meanwhile, the oxygen bridge $(\mathrm{Si}-\mathrm{O}-\mathrm{Si})$ gives silica its unique properties resulting in a very wide industrial application due to the different shapes and compositions of silica (Rayner-Canham and T., 2015).

Most silica is currently obtained from the extraction of natural materials such as waste from agriculture which is usually disposed of or burned without prior treatment and can cause pollution (Ferronato and Torretta, 2019). The large amount of

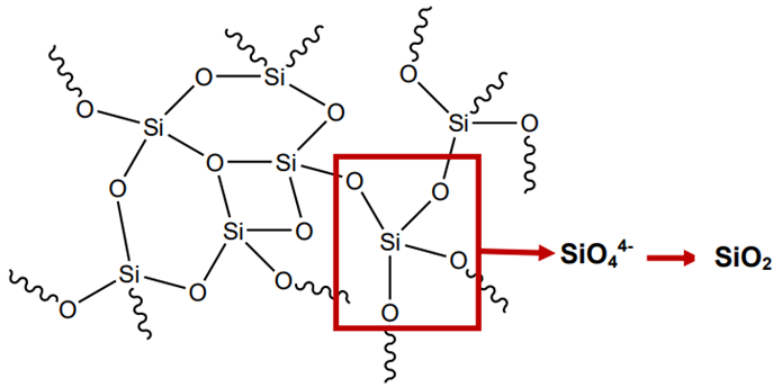

Figure 1. Structure of Bonded $\mathrm{SiO}_{4}$ to Form $\mathrm{SiO}_{2}$

waste produced each year from harvesting due to the increase of agricultural products to fulfill human needs is cause for great concern. Therefore, to reduce this problem, researchers have worked to put a use value on agricultural waste. This is widely used as a source of silica extract for further application (RaynerCanham and T., 2015; Liang et al., 2020). The increase in waste is influenced by increased production of agricultural materials. FAO statistics show a significant increase in agricultural products each year.

There have been many discussions regarding the function- 
Table 1. Quantity of Agricultural Production in the World (2016-2019) (FAOSTAT, 2021)

\begin{tabular}{ccccc}
\hline \multirow{2}{*}{ Item } & \multicolumn{4}{c}{ Production quantity (Million Ton) } \\
& 2016 & 2017 & 2018 & 2019 \\
\hline Cassava & 290.65 & 286.71 & 295.05 & 303.57 \\
Coconut & 58.46 & 57.43 & 63.76 & 62.45 \\
Maize & $1,127.35$ & $1,138.65$ & $1,124.72$ & $1,148.49$ \\
Maize, green & 11.46 & 11.41 & 9.01 & 8.3 \\
oil palm & 330.03 & 400.29 & 403.58 & 410.7 \\
Olive & 20.03 & 21.05 & 21.88 & 19.46 \\
Rice, paddy & 739.52 & 751.73 & 762.84 & 755.47 \\
Sugar cane & $1,881.08$ & $1,835.46$ & $1,930.51$ & $1,949.31$ \\
\hline
\end{tabular}

alization of silica, especially in the field of renewable energy. In the industrial world, they are found in tires, rubber, glass, cement, concrete, ceramics, textiles, paper, cosmetics, electronics, paints, films, toothpaste, health, and other industries are widely used (Setyoningrum et al., 2020). This review article will discuss more intensely the function of silica as a support material in the field of photocatalysis which has been proven to improve its performance and potential as antibacterial agents. Furthermore, this article discusses extraction methods and sources of silica from waste and its characteristics as a support material. The discussion functions to improve the study of silica sources and their use as a support material. Also, it summarizes the optimal results from the research on silica producers obtained from the nature of fabrication and its relevance in various fields.

\section{RESULTS AND DISCUSSION}

\subsection{Source of Silica}

Silica can be manufactured synthetically and extracted from the abundant amounts found in nature. This compound is also a part of the prospective minerals selected for development and application in various industrial fields (Kim et al., 2016; Lee and Yoo, 2016; Elma et al., 2020). Various studies have been conducted using natural materials, such as beach sand and agricultural waste to produce high purity silica extracts. This beach sand has a more dominant silica concentration than other oxides (Ismail et al., 2020; Eddy et al., 2015; Okereafor et al., 2020; Rattanaudom et al., 2020). Several studies have shown the results of high purity silica extraction in different sand extraction areas.

\subsubsection{Sand}

Mining products, including silica sand, are widely used in various industries, and this material is commonly known as quartz or white sand is usually found in the lowlands. It is produced from the weathering process of rocks which contain the main minerals, such as quartz and feldspar (Bernstein and Carpi, 2015). The availability of silica sand in Indonesia is very abundant (Ishmah et al., 2020), reaching 55.30-99.87 \% in 2017. Therefore, this provides benefits from various sectors in increasing its use-value (Sumarno, 2015). This material is not found in pure form but as a mixture, hence necessitating an extraction process first to obtain pure silica. Extraction is a process of separating substances from the mixture (Eddy et al., 2015). This substance has various uses in the industrial sector and usually acts as a doping or composite support or additional raw material for the manufacture of various materials. These include cement, ceramics, tiles, cast/precast, paint, cosmetics, refractory bricks, petroleum or mining, hardener in the rubber industry, and others (Madina et al., 2017).

Ishmah, 2019 succeeded in extracting silica from the sand on the beaches of Bengkulu, Indonesia. This research produced amorphous silica with a very high purity of $97.3 \%$ and was applied as a supporting photocatalyst material to remediate phenol waste. Setyoningrum et al., 2020 also succeeded in adding to the economic importance of determining silica based on its purity and the extract used was obtained from the Kokap area, Kulonprogo. According to the experimental results, the particle size reduced with an increased conversion while the increase in the amount of extracted silica was directly proportional to the $\mathrm{NaOH}$ concentration. Consequently, silica gel was the product generated from this research.

\subsubsection{Agricultural Waste \\ - Rice Husk}

Silica exists as nanoparticles and is the major inorganic constituent of rice husks ( $85-95 \%$ ) which is a derivative obtained from rice milling and husk ash through burning in a distinct boiler (Hossain et al., 2018). The ash form is an agricultural waste, hence various studies including the extraction of trapped silica, have been conducted to promote its economic value.

Klankaw et al., 2012 extracted $\mathrm{SiO}_{2}$ from rice husks coated together with $\mathrm{TiO}_{2}$ on a thin film, which was prepared on a sliding glass by using the dipping method. The best function for the photocatalytic decolorization of MB dye with a total efficiency of $81 \%$ was delivered by a thin film that consists of $\mathrm{SiO}_{2}: \mathrm{TiO}_{2}$, with values of 20:80. Furthermore, biogenic $\mathrm{SiO}_{2}$ with high purity and surface area have been previously extracted from rice husks to prepare $\mathrm{SnO}_{2} / \mathrm{SiO}_{2}$ composites. The resulting silica has an amorphous form and is obtained from the acid pathway method, where inefficient $\mathrm{SiO}_{2}$ extraction produces high purity biogenic $\mathrm{SiO}_{2}$ on the nanometer 
scale (Ferreira et al., 2015).

The chemical method for synthesizing amorphous silica nanoparticles from burnt rice straw was conducted by hydrolysis with acid-base treatment. In this case, the resulted silica particles ranged in size from $60-90 \mathrm{~nm}$ and obtained a total yield of $76.43 \%$ through physiological observations (Uda et al., 2021). Furthermore, research involving the extraction of silica has been conducted through an environmentally friendly chemical treatment approach and those with a yield of $93.08 \pm$ $0.11 \%$ were extracted from RHA. The characterization studies indicated that the difference between the commercial-grade silica $(19.49 \pm 13.03 \mathrm{~nm})$ and mean particle size of the extracted $\mathrm{SiO}_{2}$-NPs $(17.71 \pm 7.53 \mathrm{~nm}$ ) was insignificant (Nayak and Datta, 2021). According to Motlagh et al., 2020, extract silica and activated carbon simultaneously formed the two valueadded chemical products from rice waste, where the results indicated that more silica was obtained from the straw (83\%) than from the husks (66\%).

\section{- Fly Ash Waste}

Fly ash is an intricate derivative obtained from burning a variety of mineral coals (Yao et al., 2015), with an $\mathrm{SiO}_{2}$ content of 45-60 \% (Wang et al., 2020). This material is considered to be less dense than cement and to contain spherical vitreous particles with sizes ranging from 8 to $20 \mathrm{~mm}$. Besides, the synthesis of mesoporous silica, fly ash has attracted attention because of the characteristics of its resulting material (Miricioiu and Niculescu, 2020; Mehmood et al., 2017) which is rich in metal oxides, mainly silica. This substance can harm the environment Estevez et al., 2009 by interacting with water and soil which causes groundwater pollution with heavy metals, such as $\mathrm{Cr}, \mathrm{V}, \mathrm{Ni}, \mathrm{Cd}$, and Pb (Miricioiu and Niculescu, 2020). In addition, silica-rich fly ash acted as renewable source material for silica synthesis (Yadav et al., 2020).

Furthermore, nanoporous substances, such as zeolite or mesoporous silica are produced from fly ash which is used as a possible precursor due to its high silica content. These mesoporous substances, such as MCM-41 or SBA-15, are obtained from materials with a great deal of silica content and used to remove or capture $\mathrm{CO}_{2}$ from emissions or for wastewater treatment (Miricioiu and Niculescu, 2020).

Research conducted by Yadav et al., 2020 used a simple, efficient, and cost-effective alkaline fusion process for the production of nano-silica which measured 10 to $60 \mathrm{~nm}$ in spherical and aggregate shapes from fly ash-based tiles. Several studies aimed to minimize the danger of environmental ash stockpiles by reusing fly ash from biomass power plants to produce silica material. According to a previous study, the synthesized amorphous silica was successful with a purity of $44.41 \%$ to $93.63 \%$ and a yield of $20.45 \%$. The size of the agglomerate particles ranged between $380.9 \mathrm{~nm}$ to $178.8 \mathrm{~nm}$, when the ash was converted into spherical silica (Liang et al., 2020).

\section{- Cassava Waste}

Multiple studies have been performed to increase the economic value of cassava waste because the result obtained is usually disposed of carelessly or burned (Adebisi et al., 2018;
Adebisi et al., 2019; Farirai et al., 2021). Studies on the amorphous silica nanoparticles from the cassava periderm were successfully conducted using the modified sol-gel method. These results showed that the ethylene glycol-modified silica was less agglomerated with a higher yield and a lower particle size. In this study, silica nanoparticles were used as a precursor for the synthesis of silicon nanoparticles (Adebisi et al., 2017).

- Palm Ash Waste

Also, oil palm ash and other agricultural wastes are used in the synthesis of silica $\left(\mathrm{SiO}_{2}\right)$ as a renewable source of energy (Imoisili et al., 2020; Razak et al., 2019; Faizul et al., 2014; Faizul et al., 2013; Pa et al., 2016). The result, in this research, showed that silica with a purity of more than $90 \%$ could be extracted from palm ash (Pa et al., 2016).

\section{- Palm shells}

Silica nanoparticles obtained through the use of the modified sol-gel extraction technique have been successfully formed from palm shell ash. Furthermore, the microstructural analysis showed that the unit size of the extracted materials was between $50-98 \mathrm{~nm}$, with a very high specific surface area of $438 \mathrm{~m}^{2} \mathrm{~g}^{-1}$ (Imoisili et al., 2020).

\section{- Coconut Husk Ash}

Generally, coconut husks are disposed of as waste material, either by combustion or in a waste disposal site while its fruit is used globally as a source of nutrition, drink, or other products. Therefore, this material causes various environmental and health problems without proper processing or disposal methods (Anuar et al., 2020).

Research has been conducted to explain the synthesis, optical and physical properties of silica obtained from coconut coir waste, and its possible use in optical applications. Furthermore, prior to the utilization of the green synthesis method in the extraction of silica from ash after treatment with sulfuric acid, this material was burned at a temperature between $500-700{ }^{\circ} \mathrm{C}$ to produce coconut coir ash (CHA). Subsequently, the weight of the coconut husk particle size distribution was reduced from $200-750 \mathrm{~nm}$ to $200-410 \mathrm{~nm}$ at temperatures ranging between 221-360 ${ }^{\circ} \mathrm{C}$ (Anuar et al., 2020).

\section{- Olive Seed}

Investigation of silica extract from olive seeds using the alkaline leaching extraction method conducted by Naddaf et al., 2020 was successful. According to the results, the extracted powder consisted of 15-68 nm porous nanoscale silica with several hundreds of nanometer-sized particles. The resulting material which has been used for biological applications was amorphous silica which turned into a crystalline phase known as cristobalite, after sintering at $900^{\circ} \mathrm{C}$.

Silica extraction from natural materials and agricultural waste byproducts are much in demand because it provides advantages compared to other conventional methods, the advantages of this method include simple, lower costs, higher safety margins and lack of pollution produced during the synthesis process (Mor et al., 2017). 


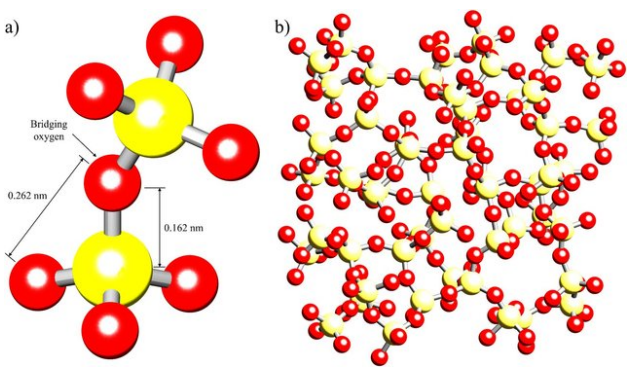

Figure 2. Atomic structure of amorphous silica. (a) Schematic representation of two tetrahedra showing nominal distances between neighbouring $\mathrm{Si}-\mathrm{O}$ and $\mathrm{O}-\mathrm{O}$ atoms, and a bridging oxygen between two neighbouring tetrahedra. (b) Subsection of an amorphous silica MD simulation showing a random arrangement of silica tetrahedra, Adapted from Lunt et al., 2018
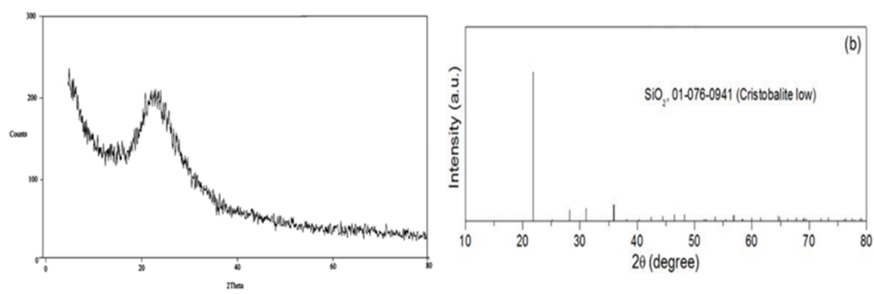

Figure 3. X-ray diffraction (XRD) spectra of $\mathrm{SiO} 2$, (a) Amorphous Adapted from Waseem et al., 2009; (b) Crystallite, Adapted from Joni et al., 2018

\subsection{Characteristic of Silica}

Silicon dioxide or silica (Figure 2) is the most abundant oxide compound form of silicon on earth with the chemical formula $\mathrm{SiO}_{2}$. The center of this structure is developed from atoms containing four oxygen fused to a tetrahedral angle site close to the silicon molecule by covalent bonds (Bernstein and Carpi, 2015; Julia, 2002). Consequently, this tetrahedral structure bonds with each other and forms a large silica matrix (Salh, 2011).

Silica material has a pore size between 5-3000 $\AA$ and can either be amorphous or quartz, which is more stable as shown in Figure 3. The bond angle around $\mathrm{O}-\mathrm{Si}-\mathrm{O}$ is $109.5^{\circ}$ which is a tetrahedral angle and varies in length between 1.54-1.69 $\AA$. The angle of the Si-O-Si (siloxane) bond varies between 120 $180^{\circ}$ which is influenced by changes in bond energy, hence allowing it to rotate freely and easily and to form amorphous or irregular structures (Julia, 2002; Yao et al., 2015; Sun et al., 2017).

This oxygen bridge (Si-O-Si) and its different shapes and compositions give silicon dioxide its unique properties. In addition, the industrial application of silica is very wide (RaynerCanham and T., 2015) due to these physical properties (Haynes, 2011):

Chemical formula : $\mathrm{SiO}_{2}$
Molar mass : $60.08 \mathrm{~g} / \mathrm{mol}$

Density : 2.648 ( $\alpha$-quartz), 2.196 (amorphous) $\mathrm{g} \cdot \mathrm{cm}^{-3}$

Melting point : $1,713^{\circ} \mathrm{C}$ (amorphous)

Boiling point : $2,950{ }^{\circ} \mathrm{C}$

Magnetic susceptibility : $-29.6 \cdot 10^{-6} \mathrm{~cm}^{3} / \mathrm{mol}$

Silica is naturally crystalline, hence it is necessary to synthesize it by certain methods to obtain an amorphous form (Julia, 2002; Yao et al., 2015). The crystalline form of silica is quite diverse and the shapes are known as polymorphs.

\subsection{Extraction Methodologies}

The silica extraction method is concerned with removing impurities or unexpected substances from the natural materials used. This substance can be extracted using several methods, including thermal and microbial processing (Uda et al., 2021).

\subsubsection{Thermal Method}

The thermal method involves heating in the form of calcination or pyrolysis. According to Venkateswaran et al., 2013, the extraction of silicon from rice husks was conducted through a thermal method that functions to remove most of the organic substances. In this study, the heating temperature was varied to see its effect on the percent Si obtained. Furthermore, after dehydration with sodium hydroxide solution, the acid-treated rice husks are used for the direct extraction of silica. Subsequently, silica is obtained from the resultant sodium silicate through the addition of an appropriate amount of mineral acid for 5-6 hours to acquire the rice husk ash (RHA) by RH pyrolysis at temperatures between $500{ }^{\circ} \mathrm{C}$ to $850{ }^{\circ} \mathrm{C}$ in a muffle furnace. The results showed that the percentage of silicon obtained increases with the calcination temperature, where absorption peaks and wavelengths of around 300-310 nm are present at $850{ }^{\circ} \mathrm{C}$. The results in this case, where the silicon powder had a pure phase formation, high purity, and good absorption peak were better than other investigations.

\subsubsection{Biological methods}

This method makes use of living things such as animals, bacteria, and fungi. Estevez et al., 2009 reported the use of California worms to extract silica from rice husks which were moistened and digested in their mouth using enzymatic fluids containing lipase, amylase, trypsinogen, etc. However, the structure of silica, which can only be completely dissolved with hydrogen hydrofluoric acid, makes the enzymes unable to react with silica. The rice husk enters the pharynx which is located in ring 6 , crushing and sucking the food and sending it to the oesophagus where the $\mathrm{pH}$ is neutralized using $\mathrm{CaCO}_{3}$. In-ring 20 , the intestine begins the process of digestion and absorption, during which the strong action of the muscles in the intestinal wall destroys food while the endocrine, pharyngeal and calciferous glands provide enzymes, such as amylases and proteases that produce degradation of organic matter. However, the mechanical work is produced by the movement of the muscles in the intestines of the worms grinding the fine silica. The 
humus is dried at room temperature, pulverized to $210 \mu \mathrm{m}$, and stored for a week in a secure plastic bag. Subsequently, this is calcined at different temperatures and the undigested sample rinsed with distilled water until a neutral $\mathrm{pH}$ was obtained and dried. This research produced high purity silica with nano-size distribution and spherical shape.

\subsubsection{Chemical method}

This method involves chemicals such as acids, bases, and other agents which are used to remove impurities and increase the purity of the silica contained in it. Apart from this, acid leaching can convert impurities into ions that are capable of dissolution (Vaibhav et al., 2015). The effect of acids in removing metal impurities from rice husks was demonstrated through the use of $\mathrm{HCl}$, which was more effective when compared to $\mathrm{H}_{2} \mathrm{SO}_{4}$, and $\mathrm{HNO}_{3}$ (Chakraverty et al., 1988).

According to Gao et al., 2019, the silica extraction from rice husks was conducted through chemical methods, where HFA was dissolved with $15 \%(1: 4.5)$ sodium hydroxide solution by weight and stored at $100{ }^{\circ} \mathrm{C}$ for 2 hours, then filtered. Furthermore, $\mathrm{NaOH}$ was added to separate the silica from impurities and to form a sodium silicate solution, which was transferred to hydrosol silica by adjusting the $\mathrm{pH}$ to 6 or 7 with the HAc solution through an ultrasonication assisted process. Consequently, the effect of $\mathrm{pH}$ on silica purity was produced and the powdered $\mathrm{SiO}_{2}$ was obtained after dehydrogenation gelation and drying. Kamath and Proctor, 1998 reported the solubility of amorphous silica to be low at $\mathrm{pH}<10$, hence a more alkaline $\mathrm{pH}$ is excellent in producing a material of high purity. The recent extensive application of this form of nano-silica in areas, including chromatography, pharmaceuticals, adsorbent materials, electronic components, drug delivery systems, catalysts, and dyes has resulted in its increasingly high demand.

Several studies were conducted using chemical methods which are widely used due to their simplicity when compared with other processes. Adebisi et al., 2017 also used this method to obtain nano-sized silica from the cassava periderm using three different routes. The acid treatment pre and post calcination are effective in reducing or removing soluble metal impurities. Furthermore, silica obtained from the pre-treatment, post-calcination process, and the ethylene glycol-modified solgel method was discovered to produce particles of higher purity that were in the nano range from 3.12 to $50.75 \mathrm{~nm}$ (Adebisi et al., 2017). Table 1 shows current research in silica extraction from natural materials.

The extraction of silica from natural materials produces different particle sizes. Particle size and size distribution are the most important characteristics of the nanoparticle system due to its influence on the properties of the material and the stability of particles. Nanoparticle-sized silica (1-100 nm) provides better activity. This is because nanoparticles have a relatively higher intracellular absorption compared to microparticles and are available for a wider range of biological targets due to their small size and relative mobility. In addition, smaller particles have a larger surface area and nanoparticle

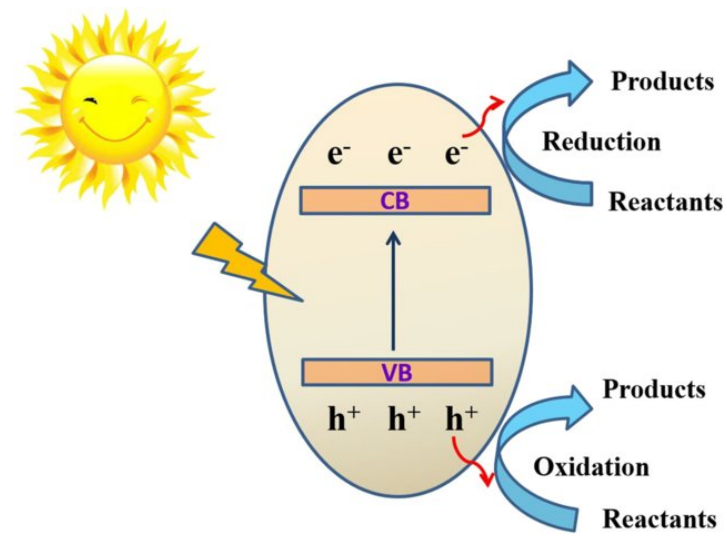

Figure 4. Photocatalytic Process in Semiconductor Materials, Adapted from He and Zhang, 2019

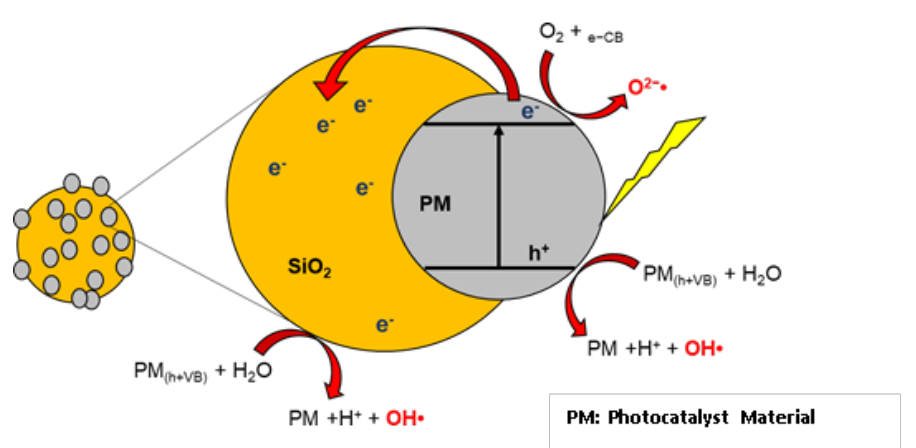

Figure 5. The Role of Silica in Photocatalyst

surface characteristics can be easily modified to produce certain properties (Li et al., 2020). Based on this, extraction methods that take into account the size of nanoparticles, eco-friendly extraction and can be widely used in most natural materials or waste is a chemical method. This method is quite simple and relatively inexpensive as well as produces good results. Nonetheless, this method needs to be adapted to the 12 principles of green chemistry to support eco-friendly and harmless for the surrounding environment.

\subsection{Extract Silica as a Supporting Material in Antibacterial Photocatalysis}

Silica has various applications, which include its role as a supporting material for a photocatalyst in the photocatalytic process. This procedure is a combination of chemical reactions that requires light elements and photocatalysts to accelerate chemical transformations (Effendy, 2010). This compound is generally a semiconductor because it has a bonding and an antibonding band separated by bandgap energy (Jal et al., 2004; Holleman A. and Wiberg, 2001). Figure 4 demonstrates this phenomenon in semiconductor materials.

Table 2 shows the difference particle size in the extraction product. In photocatalyst, particle size become an important factor that is able to influence the activity of photocatalysts. The surface structure and shape of crystals can be affected by 
Table 2. Current Research in Silica Extraction

\begin{tabular}{|c|c|c|c|c|}
\hline Starting material & Method & Products & Particle size (nm) & References \\
\hline \multirow{6}{*}{ Sand } & Chemical & Silica & - & (Triwikantoro D and Zainuri, 2015) \\
\hline & Chemical & Silica & Pore Size $15-68 \mathrm{~nm}$ & (Vaibhav et al., 2015) \\
\hline & Chemical & Silica & - & (Eddy et al., 2015) \\
\hline & Chemical & $\mathrm{SiO}_{2}$ & Macrometer & (Ishmah, 2019) \\
\hline & Sol-gel & Silica & $\sim 200 \mathrm{~nm}$ & (Ismail et al., 2020) \\
\hline & Chemical & Silica Gel & 150 mesh & (Setyoningrum et al., 2020) \\
\hline \multirow[t]{9}{*}{ Rice Husk } & Biotransformation & Silica & $152-254 \mathrm{~nm}$ & (Espindola-Gonzalez et al., 2010) \\
\hline & - & $\mathrm{SiO}_{2}$ in Thin Film & - & (Klankaw et al., 2012) \\
\hline & Acid Pre-treatment & Silica & $6 \mathrm{~nm}$ & (Rafiee et al., 2012) \\
\hline & Hydrolysis & Amorphous Silica & $50-200 \mathrm{~nm}$ & (Zemnukhova et al., 2015) \\
\hline & Leaching Calcination & Silica & $181.2-294.7 \mathrm{~nm}$ & (Carmona et al., 2013) \\
\hline & Pyrolysis & Silicon & $70-100 \mathrm{~nm}$ & (Venkateswaran et al., 2013) \\
\hline & Acid Leaching & $\mathrm{SiO}_{2}$ Biogenic Amorphous & Nanometer & (Ferreira et al., 2015) \\
\hline & - & Silica & - & (Motlagh et al., 2020) \\
\hline & - & Nanoparticle Silica Amorphous & $17.71 \pm 7.53 \mathrm{~nm}$ & (Nayak and Datta, 2021) \\
\hline \multirow[t]{2}{*}{ Palm Ashvia } & Acid Leaching & $\mathrm{SiO}_{2}$ & - & (Pa et al., 2016) \\
\hline & Sol-gel & Nanoparticle Silica & $50-98 \mathrm{~nm}$ & (Imoisili et al., 2020) \\
\hline \multirow[t]{8}{*}{ Fly Ash Waste } & Thermal & $\mathrm{SiO}_{2}$ Mesopore & $8-20 \mathrm{~mm}$ & (Permatasari et al., 2016) \\
\hline & Alkaline & Nanoparticle Silica Amorphous & $10-60 \mathrm{~nm}$ & (Yadav et al., 2020) \\
\hline & - & Nanoparticle Silica & Nanosize & (Wang et al., 2020) \\
\hline & Alkaline & Silica Amorphous & $380.9 \mathrm{~nm}-178.8 \mathrm{~nm}$ & (Liang et al., 2020) \\
\hline & Acid-base & Nanoparticle Silica Amorphous & $60-90 \mathrm{~nm}$ & (Uda et al., 2021) \\
\hline & - & Silica Nano-sorbent & $\sim 27.176 \mathrm{~nm}$ & (Chatterjee et al., 2020) \\
\hline & - & Silica Mesopore & - & (Miricioiu and Niculescu, 2020) \\
\hline & Alkaline & Silica Fume (SF) & - & (Sevinç and Durgun, 2020) \\
\hline Coconut Husk Ash & Green Synthesis & Orthorhombic Tridymite (silica) & $200-750 \mathrm{~nm}$ & (Anuar et al., 2020) \\
\hline Maize Stalk & Green Production & Silica Nanoparticles & - & (Adebisi et al., 2019) \\
\hline Olive Stones & Alkali Leaching Process & Nano-silica & Nanosize & (Naddaf et al., 2020) \\
\hline Traditional Chinese Joss Paper & Alkaline Treatment & Silica & Nanosize & (Ramanathan et al., 2020) \\
\hline Sugarcane Bagasse Ash & Alkali Leaching Process & Silica Microparticles & Microsize & (Adebisi et al., 2017) \\
\hline Cassava Waste & Sol-gel & Silica Amorphous & Nanosize & (Adebisi et al., 2017) \\
\hline Bamboo Leaves & The Box Behnken Design & Amorphous Nano-silica & - & (Olawale, 2020) \\
\hline Corn Cobs Husks & Biotransformation & Silica Nanoparticles & $\sim 40$ and $\sim 70 \mathrm{~nm}$ & (Pieła et al., 2020) \\
\hline
\end{tabular}

particle size (Cao et al., 2016; Hwang et al., 2017). Research conducted by Lin et al., 2006 successfully synthesized $\mathrm{TiO}_{2}$ nanoparticles of different particle sizes $(12-29 \mathrm{~nm})$ and found their influence on ribbon gaps indicating that particle size is capable of affecting the electro-optical properties of photo. The increase in particle size causes a decrease in the rate of photocatalytic, and vice versa ( $\mathrm{Lin}$ et al., 2006). Then the increase in photocatalyst activity is also influenced by the area of the active side (surface) of the material. The increase in particle size causes a decrease in surface area. This is because the dynamics of the charge carrier and the efficiency of the particle adsorbs change thus providing different photocatalytic activity (Cheng et al., 2013). As an antibacterial, size becomes important because the infiltration of particles in the cells in the bacteria will be easier if it has a small size (nanoparticles) so that the degradation or destruction of bacteria will be more optimal (Qi et al., 2017). The mechanisms that occur include (Sirimahachai et al., 2010; Castellote and Bengtsson, 2011; Sellapan, 2013):

- The subjection of an n-type semiconductor to light $(\gamma)$ with the appropriate energy, causing electrons (e-) in the valence band to be excited towards the conduction band and leaving a positive hole which is abbreviated as $\mathrm{h}+$, in the va- lence band.

- The $\mathrm{e}^{-}$and $\mathrm{h}^{+}$pairs will undergo recombination, either on the surface or in the bulk particles. Subsequently, the hole $\left(\mathrm{h}^{+}\right)$ will initiate an oxidation reaction and the electron $\left(\mathrm{e}^{-}\right)$will initiate a chemical reduction reaction around the semiconductor surface.

- Products resulting from a redox reaction with the environment will form radicals that have high oxidation-reduction power.

Compounds that primarily kill or retard the development of bacteria, without generally poisoning the adjacent tissue possess antibacterial action (Hajipour et al., 2012). Its mechanisms of action include inhibiting cell wall growth, resulting in changes in cell membrane permeability, inhibiting protein synthesis, and inhibiting cell nucleic acid synthesis (Ferronato and Torretta, 2019; Hajipour et al., 2012; Kim et al., 2007; Khan et al., 2020). The exact mechanism of nanoparticle toxicity to various bacteria is not fully understood (Hajipour et al., 2012) and is generally activated by the introduction of oxidative stress through the formation of free radicals, such as ROS, after administration (Sellapan, 2013; Khan et al., 2020; Yang et al., 2016). Figure 6 shows a schematic of nanoparticle toxicity.

The mechanism behind nanoscale activity in bacteria has 


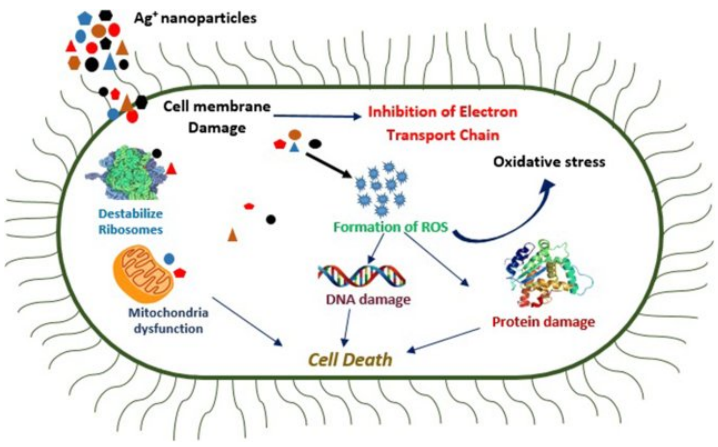

Figure 6. Proposed Mechanism of Action of Silver Nanoparticles Against Bacterial Growth/Proliferation, Adapted from Rahman et al., 2019

not been fully elucidated. The three most common mechanisms of toxicity proposed to date include the (Asharani et al., 2008):

- DNA replication and disruption of ATP production prior to the absorption of free ions

- Nanoparticles and ion generation ROS, and

- Nanoparticles direct damage to cell membranes.

Asharani et al., 2008 suggested that the concentration of $\mathrm{h}+$ is important in the reactions that occur within the mitochondria of eukaryotic cells. Likewise, when there is a proton motive force in the cell membrane, a similar mechanism can occur. ROS works against bacteria through multiple methods, including the interaction with the thiol group of enzymes and proteins which are essential for bacterial respiration. Also, by relating with the transport of essential substances across cell membranes (Cho et al., 2005), and binding to bacterial cell walls and, altering its cell membrane functions (Percival et al., 2005).

Overall, the potential of silica as supporting material for antibacterial photocatalysts can be proven by its role in increasing the produced ROS. Therefore, the review of silica application in the field of photocatalyst as a supporting material is necessary. There have been many studies discussing the effectiveness of photocatalyst performance after adding silica.

Klankaw et al., 2012 succeeded in making $\mathrm{TiO}_{2}-\mathrm{SiO}_{2}$ thin film with the extracted silica for dye degradation. This thin film is made through the self-assembly method by mixing a solution of $\mathrm{SiO}_{2}$ with titanium precursor and allowed to stand for precipitation together with silica and titanium crystals. The results showed the photocatalytic decolorization of methylene blue dye (MB) reached $81 \%$, where the advantages of $\mathrm{SiO}_{2}$ include; (1) the increase of the film absorbency and (2) the provision of hydroxyl radicals to promote the photocatalytic reaction. The photocatalytic reactivity of thin films for decolorization of MB dye depends on the increase in the specific surface area and chemical structure of the photocatalyst (Figure 7).

Mohamed et al., 2019 reported biogenic silica as the supporting material for nano polyacrylonitrile in the degradation

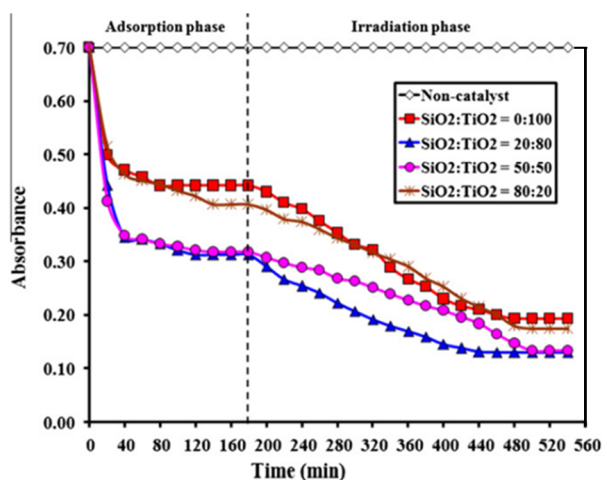

Figure 7. Decolorization of $\mathrm{MB}$ Dye of $\mathrm{TiO}_{2}-\mathrm{MCM}-41$ Thin Film at Various Molar Ratios (Klankaw et al., 2012)
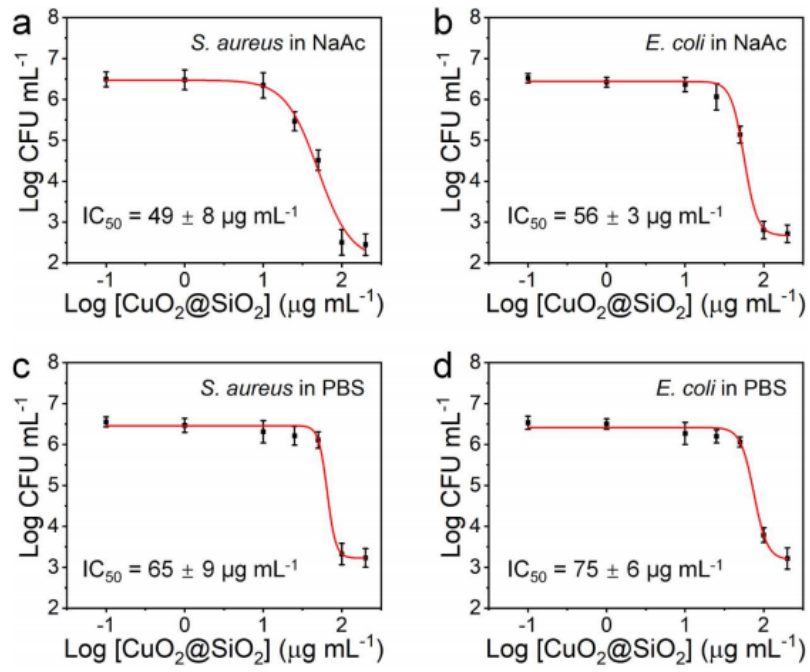

Figure 8. IC50 of $\mathrm{CuO}_{2} @ \mathrm{SiO}_{2}$. S. aureus in NaAc buffer (a) and PBS (c) and E. coli in NaAc buffer (b) and PBS (d). Red lines are the sigmoid fitting curves to obtain IC50 values, Adapted from Li et al., 2021 with American Chemical Society

of malachite green (MG) dye. An investigation was conducted on the multiple factors affecting the degradation of this color, including solution $\mathrm{pH}$, dye concentration, and irradiation time and on its photocatalytic performance under visible light in an aqueous solution. The results from the studied nanocomposite fiber demonstrated an exceptional photodegradation performance with a $98 \%$ maximum efficacy in less than 10 minutes for Malachite green. Furthermore, the fabricated fiber is used in continuous operating modes, such as fixed-bed columns because of its flexibility.

Sarkar et al., 2017 explained that doping or composite manufacturing is an active method of diffusing light absorption into the visible region. The study describes the extraction procedures for nano-silica from rice husks and the sol-gel preparation of titania-nano-silica composites for photocatalytic and photovoltaic applications. Furthermore, the extracted nano- 
silica acts as a green filler to increase the surface area of titania photocatalysts and inhibit recombination. The general plan is anticipated to increase the semiconductor activity of $\mathrm{TiO}_{2}$ by passive composites. The titania-nanosilica hybrid composites showed significant results in the application of solar cell and photocatalyst fields.

These studies prove that adding $\mathrm{SiO}_{2}$ to a photocatalyst can improve its performance. Therefore, silica can increase the adsorption power, provide hydroxyl radicals, promote photocatalytic reactions, minimize recombination, prevent agglomeration, increase thermal resistance, and increase stability against high temperatures (Bapat et al., 2016; Cho et al., 2005; Percival et al., 2005; Sarkar et al., 2017; Otero-González et al., 2014). The advantage of this silica is that it can enhance the process by improving the performance of the photocatalyst (Nilchi et al., 2010; Hou et al., 2018; Shaban et al., 2020). This also encourages the assumption that more ROS will be produced, which has a very important role in the inactivation of bacteria as previously described (Marambio-Jones and Hoek, 2010; Kim et al., 2011; Hou et al., 2018).

So far, a great deal of research have been conducted on silica as a supporting material for antibacterial photocatalysis (Zemnukhova et al., 2015; Carmona et al., 2013; Permatasari et al., 2016; Ramanathan et al., 2020; Olawale, 2020; Pieła et al., 2020). However, the silica used was synthetic as was conducted by Hou et al., 2018, in making $\mathrm{SiO}_{2}$ mesoporous spherical particles that were coated separately with $\mathrm{Ag}_{2} \mathrm{O}, \mathrm{Cu}_{2} \mathrm{O}, \mathrm{CeO}_{2}$, and $\mathrm{NiO}$ nanoparticles and used for 26 antibacterial applications. Synthesis of $\mathrm{CuO}_{2} @ \mathrm{SiO}_{2}$ as an antibacterial is also performed by Li et al., (2018) to achieve percent inactivation bacteria reached $99.9 \%$.

The bactericidal effect of the composites was tested against 27 Staphylococcus aureus in dark or LED lighting conditions. The results showed that the growth of 28 Staphylococcus aureus was severely stunted within 3 hours. Research on $\mathrm{SiO}_{2}$ produced from chemical synthetic materials has been conducted and proven to be able to be a good supporting material. Research conducted by Tan et al., (2016) showed antibacterial activity of $\mathrm{AgCl}$ and $\mathrm{AgCl} @ \mathrm{SiO}_{2}$ nanoparticles on E. Coli and explain about the role of $\mathrm{SiO}_{2}$. Researchers have successfully synthesized $\mathrm{AgCl} @ \mathrm{SiO}_{2}$ nanoparticles with a porous shellshaped $\mathrm{SiO}_{2}$ that show improved stability compared to $\mathrm{Ag}(\mathrm{I})$ samples. Silica shell protection makes nanoparticles resistant to light irradiation and can be used repeatedly. The application of $\mathrm{SiO}_{2}$ as supporting material $\mathrm{TiO}_{2}$ for antibacterial in textiles application has been done by Kartini et al., 2010. The result of this study is the increased antibacterial activity of $\mathrm{TiO}_{2} / \mathrm{SiO}_{2}$ in layered cotton which explains that the presence of $\mathrm{SiO}_{2}$ is able to increase antibacterial activity. Researchers explained the possibility of increased antibacterial activity due to the increase in coating sole adhesive to cotton fibers.

Manoharan et al., 2018 also successfully synthesized nanocomposite $\mathrm{ZnO} / \mathrm{TiO}_{2} / \mathrm{SiO}_{2}$ as antibacterial agents in cotton fabrics against E. coli bacteria (Gram negative) and Staphylococcus aureus (Gram positive) are very significant. Strong bactericidal effects

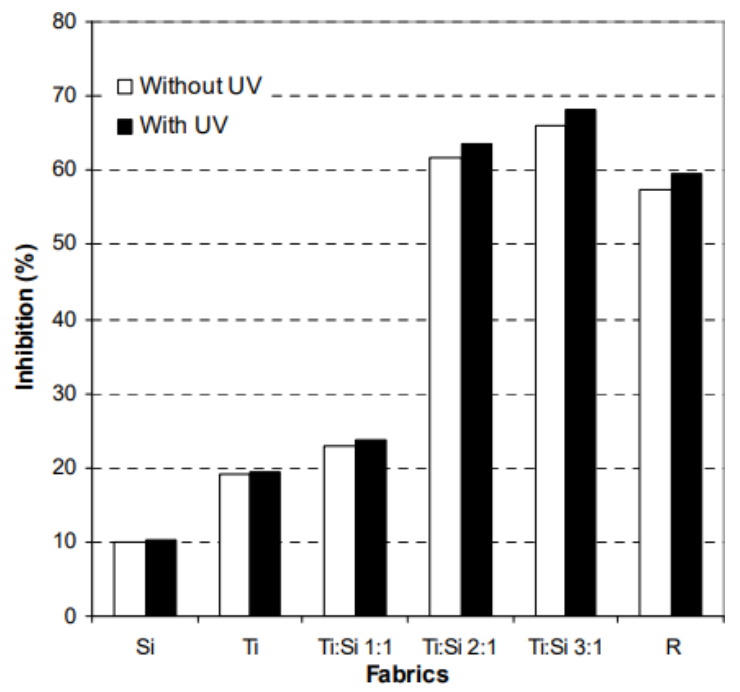

Figure 9. Antibacterial Activity of the $\mathrm{TiO}_{2}-\mathrm{SiO}_{2}$ Sols Coated Cotton Fabrics and Commercial Antibacterial Product (R) Against Escherichia coli, Adapted from Kartini et al., 2010
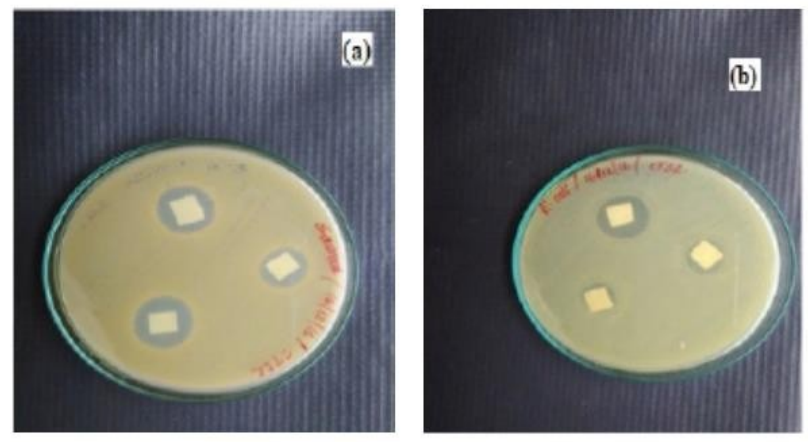

Figure 10. Antibacterial Activity of ZTS Nanocomposite Coated Cotton Fabric Against a) S. aureus area b) E. coli, Adapted from Manoharan et al., 2018

observed for nanocomposite-coated clothing for both bacteria strains had an inhibitory zone of $19 \mathrm{~mm}$ observed for $S$. aureus and $18 \mathrm{~mm}$ for E. coli.

The advantages of the hydrophobic properties of $\mathrm{SiO}_{2}$ in its antibacterial activity are explained in Zhao et al., 2020 research. In this study the fabrication of $\mathrm{MoO}_{3}-\mathrm{SiO}_{2}-\mathrm{Ag}_{2} \mathrm{O}$ was done by distributing a small amount of $\mathrm{Ag}_{2} \mathrm{O}$ separately in the amorphous $\mathrm{SiO}_{2}$ matrix. The desired antimicrobial activity to inactivate Escherichia coli, Salmonella Typhimurium and Staphylococcus aureus can be achieved due to the presence of this layer of surface hydrophobicity in $\mathrm{SiO}_{2}$, and other reasons such as the release of $\mathrm{Ag}^{+}$ions, surface acid reactions and photocatalytic activity, which can be used to reduce hospital-acquired infections.

Hoang et al., 2016 showed E.coli inactivation under UV-C irradiation using photocatalysts $\mathrm{TiO}_{2}$ (Degussa-P25), $\mathrm{TiO}_{2}{ }^{-}$ $\mathrm{SiO}_{2}$ or $1 \% \mathrm{Ag}-\mathrm{TiO}_{2}-\mathrm{SiO}_{2}$ for 30 minutes. $\mathrm{SiO}_{2}$ is signifi- 


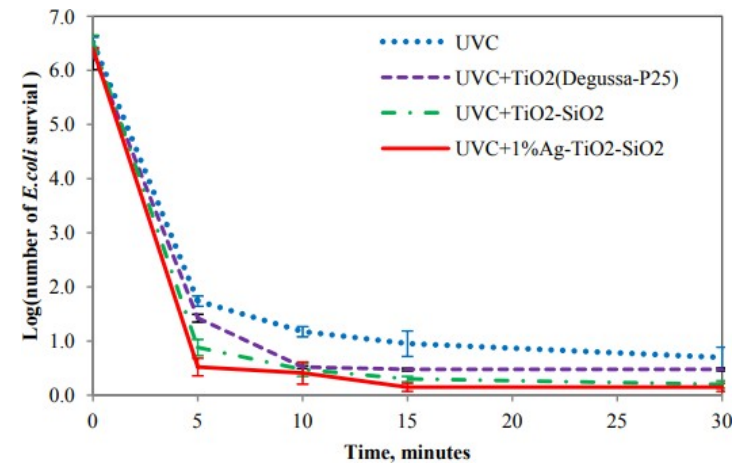

Figure 11. Inactivation Effect Against E.coli by $\mathrm{Ag}-\mathrm{TiO}_{2}-\mathrm{SiO}_{2}$ Photocatalysts under UV-C Irradiation Compared to $\mathrm{TiO}_{2}$ (Degussa-P25) and $\mathrm{TiO}_{2}-\mathrm{SiO}_{2}$, Adapted from Hoang et al., 2016

cantly capable of increasing specific surface areas compared to commercial $\mathrm{TiO}_{2}(\mathrm{P} 25)$. The higher the specific surface area of the photocatalyst the higher the area that opens between $\mathrm{UV}-\mathrm{C}$ rays and the catalyst so as increase photo-active of the catalyst. Therefore $\mathrm{TiO}_{2}-\mathrm{SiO}_{2}$ antibacterial activity is superior to commercial $\mathrm{TiO}_{2}(\mathrm{P} 25)$ under UV-C irradiation.

This proves that synthetic silica can be used as supporting material for antibacterial photocatalysts unlike those extracted from natural ingredients which are rarely used. The utilization of extracted silica is very important as a green production effort. Therefore, it can be concluded that the material has the potential to improve the performance of antibacterial photocatalysts as a species supporting material (Hou et al., 2018).

\section{CONCLUSIONS}

Silica can be produced from the extraction of natural materials such as sand, agricultural waste, and leaves. This material contains strong tetrahedral bonds which form amorphous and crystalline structures and can be extracted by several methods such as thermal, biological, or chemical methods or their combination. Silica as a photocatalyst support material is excellent for use with an increased degradation function and has the potential as supporting material for antibacterial photocatalysts.

\section{ACKNOWLEDGEMENT}

The authors are grateful to Adinda Nurfauziah, S. Hum. from State Islamic University of Sunan Gunung Djati Bandung for her helpful comments and advice. This research was funded by Research Grant from Kemenristek-BRIN 2021 with Penelitian Dasar Unggulan Perguruan Tinggi (PDUPT) Grant Number 1207/UN6.3.1/PT.00/2021 and from Universitas Padjadjaran with the Academic Leadership Grant (ALG), Prof. Iman Rahayu, Grant Number 1959/UN6.3.1/PT.00/2021.

\section{REFERENCES}

Adebisi, J., J. Agunsoye, S. Bello, I. Ahmed, O. Ojo, and S. Hassan (2017). Potential of producing solar grade silicon nanoparticles from selected agro-wastes: A review. Solar Energy, 142; 68-86

Adebisi, J., J. Agunsoye, S. Bello, M. Haris, M. Ramakokovhu, M. Daramola, and S. Hassan (2018). Extraction of silica from cassava periderm using modified sol-gel method. Nigerian Journal of Technological Development, 15(2); 57-65

Adebisi, J. A., J. O. Agunsoye, S. A. Bello, F. O. Kolawole, M. M. Ramakokovhu, M. O. Daramola, and S. B. Hassan (2019). Extraction of silica from sugarcane bagasse, cassava periderm and maize stalk: Proximate analysis and physicochemical properties of wastes. Waste and Biomass Valorization, 10(3); 617-629

Anuar, M. F., Y. W. Fen, M. H. M. Zaid, K. A. Matori, and R. E. M. Khaidir (2020). The Physical and Optical Studies of Crystalline Silica Derived from the Green Synthesis of Coconut Husk Ash. Applied Sciences, 10(6); 2128

Asharani, P., Y. L. Wu, Z. Gong, and S. Valiyaveettil (2008). Toxicity of silver nanoparticles in zebrafish models. Nanotechnology, 19(25); 1-8

Bapat, G., C. Labade, A. Chaudhari, and S. Zinjarde (2016). Silica nanoparticle based techniques for extraction, detection, and degradation of pesticides. Advances in Colloid and Interface Science, 237; 1-14

Bernstein, R. and A. Carpi (2015). Properties of Solids. Visionlearning

Cao, S., F. F. Tao, Y. Tang, Y. Li, and J. Yu (2016). Sizeand shape-dependent catalytic performances of oxidation and reduction reactions on nanocatalysts. Chemical Society Reviews, 45(17); 4747-4765

Carmona, V., R. Oliveira, W. Silva, L. Mattoso, and J. Marconcini (2013). Nanosilica from rice husk: extraction and characterization. Industrial Crops and Products, 43; 291-296

Castellote, M. and N. Bengtsson (2011). Principles of $\mathrm{TiO}_{2}$ photocatalysis. Applications of Titanium Dioxide Photocatalysis to Construction Materials, 5; 5-10

Chakraverty, A., P. Mishra, and H. Banerjee (1988). Investigation of combustion of raw and acid-leached rice husk for production of pure amorphous white silica. Journal of Materials Science, 23(1); 21-24

Chatterjee, A., S. Shamim, A. K. Jana, and J. K. Basu (2020). Insights into the competitive adsorption of pollutants on a mesoporous alumina-silica nano-sorbent synthesized from coal fly ash and a waste aluminium foil. Royal Society of Chemistry Advances, 10(26); 15514-15522

Cheng, H., W. Wang, B. Huang, Z. Wang, J. Zhan, X. Qin, X. Zhang, and Y. Dai (2013). Tailoring AgI nanoparticles for the assembly of $\mathrm{AgI} / \mathrm{BiOI}$ hierarchical hybrids with size-dependent photocatalytic activities. Journal of Materials Chemistry A, 1(24); 7131-7136

Cho, K.-H., J.-E. Park, T. Osaka, and S.-G. Park (2005). The study of antimicrobial activity and preservative effects of nanosilver ingredient. Electrochimica Acta, 51(5); 956-960

Eddy, D. R., F. N. Puri, and A. R. Noviyanti (2015). Synthesis and photocatalytic activity of silica-based sand quartz as the supporting $\mathrm{TiO}_{2}$ photocatalyst. Procedia Chemistry, 17; 55- 
58

Effendy (2010). Logam, Aloi, Semikonduktor, dan Superkonduktor. Malang: Bayumedia 514 Publishing

Elma, M., E. L. Rampun, A. Rahma, Z. L. Assyaifi, A. Sumardi, A. E. Lestari, G. S. Saputro, M. R. Bilad, and A. Darmawan (2020). Carbon templated strategies of mesoporous silica applied for water desalination: a review. Journal of Water Process Engineering, 38; 101520

Espindola-Gonzalez, A., A. Martinez-Hernández, C. AngelesChávez, V. Castano, and C. Velasco-Santos (2010). Novel crystalline $\mathrm{SiO}_{2}$ nanoparticles via annelids bioprocessing of agro-industrial wastes. Nanoscale Research Letters, 5(9); 14081417

Estevez, M., S. Vargas, V. Castano, and R. Rodriguez (2009). Silica nano-particles produced by worms through a biodigestion process of rice husk. Journal of Non-crystalline solids, 355(14-15); 844-850

Faizul, C. P., C. Abdullah, and B. Fazlul (2013). Extraction of silica from palm ash using citric acid leaching treatment: Preliminary result. Advanced Materials Research, 795; 701706

Faizul, C. P., A. Chik, M. Bari, H. J. Noorina, et al. (2014). Extraction of silica from palm ash using organic acid leaching treatment. Key Engineering Materials, 594; 329-333

FAOSTAT (2021). Agriculture and Consumer Protection. Food and Agriculture Organization

Farirai, F., M. Ozonoh, T. C. Aniokete, O. Eterigho-Ikelegbe, M. Mupa, B. Zeyi, and M. O. Daramola (2021). Methods of extracting silica and silicon from agricultural waste ashes and application of the produced silicon in solar cells: a minireview. International Journal of Sustainable Engineering, 14(1); $57-78$

Ferreira, C. S., P. L. Santos, J. A. Bonacin, R. R. Passos, and L. A. Pocrifka (2015). Rice husk reuse in the preparation of $\mathrm{SnO}_{2} / \mathrm{SiO}_{2}$ nanocomposite. Materials Research, 18(3); 639-643

Ferronato, N. and V. Torretta (2019). Waste mismanagement in developing countries: A review of global issues. International Journal of Environmental Research and Public Health, 16(6); 1060

Gao, Q., J. Xu, and X.-H. Bu (2019). Recent advances about metal-organic frameworks in the removal of pollutants from wastewater. Coordination Chemistry Reviews, 378; 17-31

Hajipour, M. J., K. M. Fromm, A. A. Ashkarran, D. J. de Aberasturi, I. R. de Larramendi, T. Rojo, V. Serpooshan, W. J. Parak, and M. Mahmoudi (2012). Antibacterial properties of nanoparticles. Trends in Biotechnology, 30(10); 499511

Haynes, W. M. (2011). CRC Handbook of Chemistry and Physics (92nd ed.) ISBN 551 1439855110. Boca Raton FL: CRC Press

He, X. and C. Zhang (2019). Recent advances in structure design for enhancing photocatalysis. Journal of Materials Science, 54(12); 8831-8851

Hoang, N. T.-T., A. T.-K. Tran, N. Van Suc, et al. (2016). An- tibacterial activities of gel-derived $\mathrm{Ag}-\mathrm{TiO}_{2}-\mathrm{SiO}_{2}$ nanomaterials under different light irradiation. AIMS Materials Science, 3(2); 339-348

Holleman A., F. and E. Wiberg (2001). Inorganic Chemistry, translated by Eagleson, Mary, Brewer, William. San Diego/Berlin: Academic Press/De Gruyter

Hossain, S. S., L. Mathur, and P. Roy (2018). Rice husk/rice husk ash as an alternative source of silica in ceramics: A review. Journal of Asian Ceramic Societies, 6(4); 299-313

Hou, Y.-x., H. Abdullah, D.-h. Kuo, S.-j. Leu, N. S. Gultom, and C.-H. Su (2018). A comparison study of $\mathrm{SiO}_{2} /$ nano metal oxide composite sphere for antibacterial application. Composites Part B: Engineering, 133; 166-176

Hwang, Y. J., S. Yang, and H. Lee (2017). Surface analysis of $\mathrm{N}$-doped $\mathrm{TiO}_{2}$ nanorods and their enhanced photocatalytic oxidation activity. Applied Catalysis B: Environmental, 204; 209-215

Imoisili, P. E., K. O. Ukoba, and T.-C. Jen (2020). Green technology extraction and characterisation of silica nanoparticles from palm kernel shell ash via sol-gel. Journal of Materials Research and Technology, 9(1); 307-313

Ishmah, S. N. (2019). Ekstraksi Silika Pasir Pantai Bengkulu Sebagai Pendukung Fotokatalis Titanium Dioksida Dalam Remediasi Limbah. Univeristas Padjadjaran

Ishmah, S. N., M. D. Permana, M. L. Firdaus, and D. R. Eddy (2020). Extraction of Silica from Bengkulu Beach Sand using Alkali Fusion Method. PendIPA Journal of Science Education, $4 ; 1-5$

Ismail, A., A. L. Widyaningtyas, B. H. Susanto, and M. Nasikin (2020). Facile Synthesis Silica Nanoparticles from Indonesia Silica Sand and their Physico-Chemical Properties. Key Engineering Materials, 862; 35-39

Jal, P., M. Sudarshan, A. Saha, S. Patel, and B. Mishra (2004). Synthesis and characterization of nanosilica prepared by precipitation method. Colloids and Surfaces A: Physicochemical and Engineering Aspects, 240(1); 173-178

Joni, I., L. Nulhakim, M. Vanitha, and C. Panatarani (2018). Characteristics of crystalline silica $\left(\mathrm{SiO}_{2}\right)$ particles prepared by simple solution method using sodium silicate $\left(\mathrm{Na}_{2} \mathrm{SiO}_{3}\right)$ precursor. Journal of Physics: Conference Series, 1080(1); 12006

Julia, D. L. (2002). Silica-Titania Composite for Water Treatment. University of Florida, USA

Kamath, S. R. and A. Proctor (1998). Silica gel from rice hull ash: preparation and characterization. Cereal Chemistry Journal, 75(4); 484-487

Kartini, I., E. S. Kunarti, E. T. Wahyuni, I. Purwantini, C. Wiedyaningsih, and R. Listyawati (2010). Antibacterial Coating Of Titania-Silica Nanosols On Cotton Fabrics. The 2nd International Conference on Chemical Sciences Proceeding, ISSN NO. 1410-8313

Khan, K., M. F. Ullah, K. Shahzada, M. N. Amin, T. Bibi, N. Wahab, and A. Aljaafari (2020). Effective use of microsilica extracted from rice husk ash for the production of highperformance and sustainable cement mortar. Construction 
and Building Materials, 258; 119589

Kim, M.-K., J.-A. Lee, M.-R. Jo, and S.-J. Choi (2016). Bioavailability of silica, titanium dioxide, and zinc oxide nanoparticles in rats. Journal of Nanoscience and Nanotechnology, 16(6); 6580-6586

Kim, S.-H., H.-S. Lee, D.-S. Ryu, S.-J. Choi, and D.-S. Lee (2011). Antibacterial activity of silver-nanoparticles against Staphylococcus aureus and Escherichia coli. Microbiology and Biotechnology Letters, 39(1); 77-85

Kim, Y. H., D. K. Lee, H. G. Cha, C. W. Kim, and Y. S. Kang (2007). Synthesis and characterization of antibacterial Ag$\mathrm{SiO}_{2}$ nanocomposite. The Journal of Physical Chemistry $\mathrm{C}$, 111(9); 3629-3635

Klankaw, P., C. Chawengkijwanich, N. Grisdanurak, and S. Chiarakorn (2012). The hybrid photocatalyst of $\mathrm{TiO}_{2}-$ $\mathrm{SiO}_{2}$ thin film prepared from rice husk silica. Superlattices and Microstructures, 51(3); 343-352

Lee, D. W. and B. R. Yoo (2016). Advanced silica/polymer composites: Materials and applications. Journal of Industrial and Engineering Chemistry, 38; 1-12

Li, D., H. Song, X. Meng, T. Shen, J. Sun, W. Han, and $\mathrm{X}$. Wang (2020). Effects of particle size on the structure and photocatalytic performance by alkali-treated $\mathrm{TiO}_{2}$. Nanomaterials, 10(3); 546

Li, X., M. Liang, S. Jiang, S. Cao, S. Li, Y. Gao, J. Liu, Q. Bai, N. Sui, and Z. Zhu (2021). Pomegranate-Like CuO @ $\mathrm{SiO}_{2}$ Nanospheres as $\mathrm{H}_{2} \mathrm{O}_{2}$ Self-Supplying and Robust Oxygen Generators for Enhanced Antibacterial Activity. ACS Applied Materials Eீ Interfaces, 13(19); 22169-22181

Liang, G., Y. Li, C. Yang, C. Zi, Y. Zhang, X. Hu, and W. Zhao (2020). Production of biosilica nanoparticles from biomass power plant fly ash. Waste Management, 105; 8-17

Lin, H., C. Huang, W. Li, C. Ni, S. I. Shah, and Y.-H. Tseng (2006). Size dependency of nanocrystalline $\mathrm{TiO}_{2}$ on its optical property and photocatalytic reactivity exemplified by 2-chlorophenol. Applied Catalysis B: Environmental, 68(1-2); $1-11$

Lunt, A. J., P. Chater, and A. M. Korsunsky (2018). On the origins of strain inhomogeneity in amorphous materials. Scientific Reports, 8(1); 1-8

Lutgens, F. K. and E. J. Tarbuck (2000). Essentials of Geology, 7 th Ed. Prentice-Hall

Madina, F. E., R. Elvia, and I. N. Candra (2017). Synthesis of Silica from The Sand of Panjang Beach and Its Application for Rhodamine B Adsorption. Jurnal Pendidikan dan Ilmu Kimia, 1(2); 98-101

Manoharan, C., V. Rajendran, and R. Sivaraj (2018). Synthesis, characterization and applications of Zno/Tio2/Sio2 nanocomposite. Oriental Journal of Chemistry, 34(3); 1333

Marambio-Jones, C. and E. M. Hoek (2010). A review of the antibacterial effects of silver nanomaterials and potential implications for human health and the environment. Journal of Nanoparticle Research, 12(5); 1531-1551

Matichenkov, V. and D. Calvert (2002). Silicon as a beneficial element for sugarcane. Journal American Society of Sugarcane
Technologists, 22(2); 21-30

Mehmood, A., H. Ghafar, S. Yaqoob, U. F. Gohar, and B. Ahmad (2017). Mesoporous silica nanoparticles: a review. Journal of Drug and Research Development, 6(2)

Miricioiu, M. G. and V.-C. Niculescu (2020). Fly ash, from recycling to potential raw material for mesoporous silica synthesis. Nanomaterials, 10(3); 474

Mohamed, A., M. M. Ghobara, M. Abdelmaksoud, and G. G. Mohamed (2019). A novel and highly efficient photocatalytic degradation of malachite green dye via surface modified polyacrylonitrile nanofibers/biogenic silica composite nanofibers. Separation and Purification Technology, 210; 935-942

Mor, S., C. K. Manchanda, S. K. Kansal, and K. Ravindra (2017). Nanosilica extraction from processed agricultural residue using green technology. Journal of Cleaner Production, $143 ; 1284-1290$

Motlagh, E. K., N. A. Kolur, S. M. Sharifian, and A. E. Pirbazari (2020). Effect of Silica Extraction on the Porous Structure and Surface Area of Activated Carbon Prepared from Rice Wastes. Irish Centre for High-End Computing; 1517

Naddaf, M., H. Kafa, and I. Ghanem (2020). Extraction and characterization of Nano-silica from olive stones. Silicon, 12(1); 185-192

Nayak, P. and A. Datta (2021). Synthesis of $\mathrm{SiO}_{2}$-nanoparticles from rice husk ash and its comparison with commercial amorphous silica through material characterization. Silicon, 13(4); 1209-1214

Nilchi, A., S. Janitabar-Darzi, A. Mahjoub, and S. RasouliGarmarodi (2010). New $\mathrm{TiO}_{2} / \mathrm{SiO}_{2}$ nanocomposites-Phase transformations and photocatalytic studies. Colloids and Surfaces A: Physicochemical and Engineering Aspects, 361(1-3); $25-30$

Okereafor, U., M. Makhatha, L. Mekuto, and V. Mavumengwana (2020). Gold Mine Tailings: A Potential Source of Silica Sand for Glass Making. Minerals, 10(5); 448

Olawale, O. (2020). Bamboo leaves as an alternative source for silica in ceramics using Box Benhken design. Scientific African, 8; 418

Otero-González, L., I. Barbero, J. A. Field, F. Shadman, and R. Sierra-Alvarez (2014). Stability of alumina, ceria, and silica nanoparticles in municipal wastewater. Water Science and Technology, 70(9); 1533-1539

Pa, F. C., A. Chik, and M. F. Bari (2016). Palm ash as an alternative source for silica production. MATEC Web of Conferences, 78; 1062

Percival, S. L., P. Bowler, and D. Russell (2005). Bacterial resistance to silver in wound care. Journal of Hospital Infection, $60(1) ; 1-7$

Permatasari, N., T. N. Sucahya, and A. B. D. Nandiyanto (2016). Agricultural wastes as a source of silica material. Indonesian Journal of Science and Technology, 1(1); 82-106

Pieła, A., E. Żymańczyk-Duda, M. Brzezińska-Rodak, M. Duda, J. Grzesiak, A. Saeid, M. Mironiuk, and M. Klimek-Ochab (2020). Biogenic synthesis of silica 
nanoparticles from corn cobs husks. Dependence of the productivity on the method of raw material processing. Bioorganic Chemistry, 99; 103773

Qi, K., B. Cheng, J. Yu, and W. Ho (2017). Review on the improvement of the photocatalytic and antibacterial activities of ZnO. Journal of Alloys and Compounds, 727; 792-820

Rafiee, E., S. Shahebrahimi, M. Feyzi, and M. Shaterzadeh (2012). Optimization of synthesis and characterization of nanosilica produced from rice husk (a common waste material). International Nano Letters, 2(1); 1-8

Rahman, S., L. Rahman, A. T. Khalil, N. Ali, D. Zia, M. Ali, and Z. K. Shinwari (2019). Endophyte-mediated synthesis of silver nanoparticles and their biological applications. Applied Microbiology and Biotechnology, 103(6); 2551-2569

Ramanathan, S., S. C. Gopinath, M. M. Arshad, P. Poopalan, P. Anbu, T. Lakshmipriya, and C.-G. Lee (2020). Alkalinized extraction of silica-aluminium nanocomposite from traditional Chinese joss paper: optical characterizations. $\mathrm{Ma}$ terials Chemistry and Physics, 243; 122621

Rattanaudom, P., B.-J. Shiau, U. Suriyapraphadilok, and A. Charoensaeng (2020). Effect of $\mathrm{pH}$ on silica nanoparticlestabilized foam for enhanced oil recovery using carboxylatebased extended surfactants. Journal of Petroleum Science and Engineering, 192; 107729

Rayner-Canham, G. and O. T. (2015). Descriptive Inorganic Chemistry, 1st ed. New York: W. H. Freeman and Company

Razak, H., N. Abdullah, H. Setiabudi, C. Yee, and N. Ainirazali (2019). Influenced of Ni loading on SBA-15 synthesized from oil Palm ash silica for syngas production. IOP Conference Series: Materials Science and Engineering, 702(1); 12024

Salh, R. (2011). Defect related luminescence in silicon dioxide network: a review. InTech Rijeka

Sarkar, P., S. A. Moyez, A. Dey, S. Roy, and S. K. Das (2017). Experimental investigation of photocatalytic and photovoltaic activity of titania/rice husk crystalline nanosilica hybrid composite. Solar Energy Materials and Solar Cells, 172; 93-98

Sellapan, R. (2013). Mechanisms of Enhanced Activity of Model $\mathrm{TiO}_{2} /$ Carbon and $\mathrm{TiO}_{2} /$ Metal Nanocomposite Photocatalysts. Chalmers University

Setyoningrum, T. M., S. W. Murni, and W. W. Nandari (2020). Extraction of Silica from Kalirejo Minerals, Kokap, Kulonprogo, Yogyakarta. Proceeding of LPPM UPN “Veteran" Yogyakarta Conference Series 2020-Engineering and Science Series, 1(1); 269-276

Sevinç, A. H. and M. Y. Durgun (2020). Properties of highcalcium fly ash-based geopolymer concretes improved with high-silica sources. Construction and Building Materials, 261; 120014

Shaban, M., A. Hamd, R. R. Amin, M. R. Abukhadra, A. A. Khalek, A. A. P. Khan, and A. M. Asiri (2020). Preparation and characterization of MCM-48/nickel oxide composite as an efficient and reusable catalyst for the assessment of photocatalytic activity. Environmental Science and Pollution Research, 27(26); 1-13
Sirimahachai, U., N. Ndiege, R. Chandrasekharan, S. Wongnawa, and M. A. Shannon (2010). Nanosized $\mathrm{TiO}_{2}$ particles decorated on $\mathrm{SiO}_{2}$ spheres $\left(\mathrm{TiO}_{2} / \mathrm{SiO}_{2}\right)$ : synthesis and photocatalytic activities. Journal of Sol-gel Science and Technology, 56(1); 53-60

Sumarno, S. (2015). Pemurnian Pasir Silika dengan Metode Leaching Asam dan bantuan Sonikasi. Seminar Nasional Teknik Kimia Kejuangan; 1-3

Sun, J., Z. Xu, W. Li, and X. Shen (2017). Effect of nano$\mathrm{SiO}_{2}$ on the early hydration of alite-sulphoaluminate cement. Nanomaterials, 7(5); 102

Triwikantoro D, M. and M. Zainuri (2015). Synthesis of $\mathrm{SiO}_{2}$ nanopowders containing quartz and cristobalite phases from silica sands. Materials Science-Poland, 33(1); 47-55

Uda, M., S. C. Gopinath, U. Hashim, N. Halim, N. Parmin, M. Afnan Uda, and P. Anbu (2021). Production and characterization of silica nanoparticles from fly ash: conversion of agro-waste into resource. Preparative Biochemistry \& Biotechnology, 51(1); 86-95

Vaibhav, V., U. Vijayalakshmi, and S. M. Roopan (2015). Agricultural waste as a source for the production of silica nanoparticles. Spectrochimica Acta Part A: Molecular and Biomolecular Spectroscopy, 139; 515-520

Venkateswaran, S., R. Yuvakkumar, and V. Rajendran (2013). Nano silicon from nano silica using natural resource (RHA) for solar cell fabrication. Phosphorus, Sulfur, and Silicon and the Related Elements, 188(9); 1178-1193

Wang, J., M. Liu, Y. Wang, Z. Zhou, D. Xu, P. Du, and X. Cheng (2020). Synergistic effects of nano-silica and fly ash on properties of cement-based composites. Construction and Building Materials, 262; 120737

Waseem, M., S. Mustafa, A. Naeem, and K. Shah (2009). Synthesis and characterization of silica by sol-gel method. Journal of Pakistan Materials Society, 3(1); 19-21

Yadav, V. K., R. Suriyaprabha, S. H. Khan, B. Singh, G. Gnanamoorthy, N. Choudhary, A. K. Yadav, and H. Kalasariya (2020). A novel and efficient method for the synthesis of amorphous nanosilica from fly ash tiles. Materials Today: Proceedings, 26; 701-705

Yang, S.-J., X. Chen, B. Yu, H.-L. Cong, Q.-H. Peng, and M.M. Jiao (2016). Self-cleaning superhydrophobic coatings based on PDMS and $\mathrm{TiO}_{2} / \mathrm{SiO}_{2}$ nanoparticles. Integrated Ferroelectrics, 169(1); 29-34

Yao, Z. T., X. S. Ji, P. Sarker, J. Tang, L. Ge, M. Xia, and Y. Xi (2015). A comprehensive review on the applications of coal fly ash. Earth-Science Reviews, 141; 105-121

Zemnukhova, L. A., A. E. Panasenko, A. P. Artem'yanov, and E. A. Tsoy (2015). Dependence of porosity of amorphous silicon dioxide prepared from rice straw on plant variety. BioResources, 10(2); 3713-3723

Zhao, Y., J. Xu, Z. Li, T. Fu, and S. Jiang (2020). In vitro antibacterial properties of $\mathrm{MoO}_{3} / \mathrm{SiO}_{2} / \mathrm{Ag}_{2} \mathrm{O}$ nanocomposite coating prepared by double cathode glow discharge technique. Surface and Coatings Technology, 397; 125992 